\title{
Digital PCR analysis of plasma cell-free DNA for non-invasive detection of drug resistance mechanisms in EGFR mutant NSCLC: Correlation with paired tumor samples
}

\author{
Hidenobu Ishii ${ }^{1}$ Koichi Azuma ${ }^{1}$, Kazuko Sakai ${ }^{2}$, Akihiko Kawahara ${ }^{3}$, \\ Kazuhiko Yamada ${ }^{1}$, Takaaki Tokito ${ }^{1}$, Isamu Okamoto ${ }^{4}$, Kazuto Nishio ${ }^{2}$, \\ Tomoaki Hoshino ${ }^{1}$ \\ ${ }^{1}$ Division of Respirology, Neurology, and Rheumatology, Department of Internal Medicine, Kurume University School of \\ Medicine, Kurume, Fukuoka, Japan \\ ${ }^{2}$ Department of Genome Biology, Kinki University Faculty of Medicine, Osaka, Japan \\ ${ }^{3}$ Department of Diagnostic Pathology, Kurume University Hospital, Kurume, Fukuoka, Japan \\ ${ }^{4}$ Center for Clinical and Translational Research, Kyusyu University Hospital, Fukuoka, Japan \\ Correspondence to: \\ Koichi Azuma, e-mail: azuma@med.kurume-u.ac.jp \\ Keywords: T790M mutation, cell-free DNA, digital PCR, EGFR, non-small-cell lung cancer
}

Received: May 20, 2015

Accepted: August 04, 2015

Published: August 17, 2015

\section{ABSTRACT}

As the development of resistance to epidermal growth factor receptor (EGFR) tyrosine kinase inhibitors (TKIs) has become an issue of concern, identification of the mechanisms responsible has become an urgent priority. However, for research purposes, it is not easy to obtain tumor samples from patients with EGFR mutationpositive non-small-cell lung cancer (NSCLC) that has relapsed after treatment with EGFR-TKIs. Here, using digital PCR assay as an alternative and noninvasive method, we examined plasma and tumor samples from patients with relapsed NSCLC to establish the inter-relationships existing among T790M mutation, activating EGFR mutations, HER2 amplification, and MET amplification. Paired samples of tumor and blood were obtained from a total of 18 patients with NSCLC after they had developed resistance to EGFR-TKI treatment, and the mechanisms of resistance were analyzed by digital PCR. Digital PCR analysis of T790M mutation in plasma had a sensitivity of $\mathbf{8 1 . 8} \%$ and specificity of $\mathbf{8 5 . 7 \%}$, the overall concordance between plasma and tissue samples being $\mathbf{8 3 . 3 \%}$. MET gene copy number gain in tumor DNA was observed by digital PCR in three patients, of whom one exhibited positivity for MET amplification by FISH, whereas no patient demonstrated MET and HER2 copy number gain in plasma DNA. Digital PCR analysis of plasma is feasible and accurate for detection of T790M mutation in NSCLC that becomes resistant to treatment with EGFR-TKIs.

\section{INTRODUCTION}

Non-small-cell lung cancer (NSCLC) is the leading cause of cancer death worldwide [1]. Recent therapeutic strategies for NSCLC have focused on the development of molecular targeted therapies. Somatic mutations in the epidermal growth factor receptor $(E G F R)$ gene have been identified as a major determinant of the clinical response to treatment with EGFR tyrosine kinase inhibitors (EGFRTKIs) such as gefitinib, erlotinib and afatinib in individuals with NSCLC [2-7]. Although patients with EGFR mutation-positive NSCLC typically show good responses to EGFR-TKIs, resistance eventually develops after 9 to 14 months. Several mechanisms of acquired resistance to EGFR TKIs have been identified, including a second-site point mutation that substitutes methionine for threonine at position $790(\mathrm{~T} 790 \mathrm{M})$ in the EGFR, amplification of the mesenchymal-epithelial transition (MET) protooncogene and human epidermal growth factor receptor 2 (HER2), and small-cell lung cancer transformation [8-10]. The most common event responsible for resistance is acquisition of the T790M mutation, which occurs in over 
$50 \%$ of patients who initially respond to EGFR-TKIs [8]. Current clinical approaches for overcoming resistance to EGFR-TKIs in NSCLC include the use of mutantselective inhibitors of EGFR, a combination of cetuximab and afatinib, and a combination of EGFR-TKI with a drug inhibiting a resistance pathway, for example erlotinib used together with a MET inhibitor [10-14].

Although tumor samples are required for studying the mechanism of resistance to EGFR-TKIs, it is difficult to obtain such samples from patients with NSCLC who have acquired such resistance. The level of tumor cell-free DNA (cfDNA) in plasma specimens is reportedly higher in patients with lung cancer than in those without cancer [15]. Here, we evaluated the application of digital PCR analysis to plasma samples as an alternative and non-invasive method for investigating the mechanisms of resistance to EGFR-TKIs, including T790M resistance mutation and amplification of MET and HER2, in comparison with results obtained using tumor samples.

\section{RESULTS}

\section{Patient characteristics and efficacy of EGFR-TKI treatment}

Patient characteristics are shown in Table 1. Among the 18 patients, 16 were female and 2 were male. Seven patients had E746-A750 deletion in exon 19, 10 had L858R point mutation in exon 21, and one had a minor mutation involving S752-I759 deletion in exon 19. One patient received elrotinib and the others received gefitinib as initial EGFR-TKI treatment. The EGFR-TKI treatment was provided as the first-line chemotherapy in 13 patients, the second line in three, the third line in one, and the fourth line in one. The overall rate of response to initial EGFRTKI treatment was $72.2 \%$, with a median progression-free survival 11.7 months. Tumor specimens after acquisition of resistance to EGFR-TKI treatment were derived from the primary lung lesion in 7 patients, pleural effusion in 8 , lymph node metastasis in 2 , and pericardial effusion in one.

\section{Consistency of primary activating EGFR mutation between tumor and plasma}

The results relating to the consistency of primary active EGFR mutation status with tumor and plasma cfDNA are shown in Table 2 and summarized in Table 3. One patient (Case 1) who had a minor mutation involving S752-I759 deletion in exon 19 was not evaluable. Of the remaining 17 patients, 15 had detectable activating EGFR mutation in the tumor, whereas 10 patients exhibited this in the plasma cfDNA. All mutation types in these patients were consistent with the primary EGFR mutation status detected before treatment.

\section{Consistency of T790M mutation between tumor and plasma}

Ten T790M mutations were detected from all 18 plasma specimens, whereas 11 T790M mutations were found in the paired tumor samples (Table 2). Notably, one patient with plasma cfDNA T790M mutation had no T790M mutation in the corresponding tumor DNA sample, and two patients with T790M mutations in tumor DNA specimens had no T790M mutation in the corresponding plasma. The sensitivity and specificity of digital PCR analysis for T790M mutation in plasma was $81.8 \%$ and $85.7 \%$, respectively, and the overall concordance between plasma and tumor samples was $83.3 \%(15 / 18)$. The correlation between T790M mutations detected in the plasma and tumor samples is summarized in Table 3.

\section{Detection of $M E T$ and $H E R 2$ copy number}

Analysis of tumor samples confirmed a gain of the MET copy number in three patients. However, FISH analysis demonstrated MET amplification in only one patient (Case 9), and no patients showed an increase of the $M E T$ copy number in plasma. HER 2 copy number gain in the tumor and cfDNA were analyzed by digital PCR. However, no copy number gain was detected in any of the 18 cases (data not shown).

\section{DISCUSSION}

In this study using digital PCR assay as an alternative and non-invasive method for examining plasma and tumor samples, we investigated correlations among T790M mutation, activating EGFR mutations, HER2 amplification, and MET amplification in patients with NSCLC relapse after treatment with EGFR-TKIs. Although previous studies have examined various techniques for non-invasive detection of EGFR mutations in NSCLC patients, such as amplification refractory mutation systems, denaturing high-performance liquid chromatography, multi-threaded electronic polymerase chain reaction, and direct sequencing, the results have been inconclusive, with sensitivities ranging from $43.1 \%$ to $81.2 \%$ [16-23]. Yung et al. demonstrated that digital PCR analysis had a high sensitivity of $91.7 \%$ for detection of EGFR mutation in plasma samples [24], suggesting that it would be a promising method for T790M analysis of plasma cfDNA. Digital PCR is both a qualitative and quantitative method, being capable of detecting genetic alterations with a high specificity of up to $0.001 \%$ [25]. It has been reported that digital PCR analysis has high sensitivity and a high detection ratio in comparison with an allele-specific PCR technique such as scorpionARMS [26]. Given the high rates of false negativity for EGFR mutation in plasma cfDNA [27], we investigated the 
Table 1: Patient and tumor characteristics

\begin{tabular}{|c|c|}
\hline Number & 18 \\
\hline \multicolumn{2}{|l|}{ Age (years) } \\
\hline Median & 66 \\
\hline Range & $50-81$ \\
\hline \multicolumn{2}{|l|}{ Sex } \\
\hline Male & 2 \\
\hline Female & 16 \\
\hline \multicolumn{2}{|l|}{ Smoking status } \\
\hline Current/Former & 1 \\
\hline Never & 17 \\
\hline \multicolumn{2}{|l|}{ Histology } \\
\hline Adenocarcinoma & 18 \\
\hline \multicolumn{2}{|c|}{ Type of EGFR mutation } \\
\hline E746-A750 del & 7 \\
\hline L858R & 10 \\
\hline S752-I759 del & 1 \\
\hline \multicolumn{2}{|l|}{ Initial TKI treatment } \\
\hline Gefitinib & 17 \\
\hline Erlotinib & 1 \\
\hline \multicolumn{2}{|l|}{ TKI treatment line } \\
\hline $1 \mathrm{st}$ & 13 \\
\hline $2 \mathrm{nd}$ & 3 \\
\hline $3 \mathrm{rd}$ & 1 \\
\hline 4th & 1 \\
\hline
\end{tabular}

Abbreviations: EGFR, epidermal growth factor receptor; TKI, tyrosine kinase inhibitor.

utility of digital PCR analysis as a highly sensitive assay for clarifying the mechanism of resistance to EGFR-TKIs. Although other researchers have investigated the detection of T790M mutant alleles in plasma cfDNA, they mostly focused on factors predictive of EGFR-TKI treatment outcome, such as monitoring of T790M mutation [28-31]. In this study, we found that digital PCR analysis of T790M mutation in plasma had a high sensitivity of $81.8 \%$ and a specificity of $85.7 \%$, and that the overall concordance between plasma and tissue samples was $83.3 \%$. Using a highly accurate method of digital PCR analysis, our study demonstrated relatively high concordance with previous studies that had investigated EGFR mutation status in pre-treatment samples [16-23]. These results suggest that digital PCR may be a feasible and clinically applicable method for detection of T790M mutation in plasma cfDNA. As far as we are aware, no previous study has demonstrated a significant correlation of T790M mutation between tumor samples and plasma cfDNA in individuals with EGFR-mutant NSCLC that has acquired resistance to EGFR-TKIs. Recently, third-generation EGFR-TKIs have yielded promising results in patients with EGFR-mutation positive NSCLC resistant to existing EGFR-TKIs [11, 12]. These new drugs were designed to inhibit both the activating EGFR mutation in patients with NSCLC as well as the T790M resistance mutation, and showed a high positive response rate to T790M mutation-positive NSCLC of approximately $60 \%$ in phase I clinical trials [32]. Although it is necessary to accurately identify T790M mutation-positive patients for proper use of these drugs, there are untestable patients such as those in whom tumor lesions cannot be acquired safely, or those who do not consent to re-biopsy. Given the high sensitivity and specificity of T790M detection in plasma samples, digital 
Table 2: Analysis of resistance mechanism to EGFR-TKI treatment in tumor samples and plasma samples

\begin{tabular}{|c|c|c|c|c|c|c|c|c|c|c|}
\hline \multirow[t]{2}{*}{ Case } & \multirow{2}{*}{$\begin{array}{l}\text { Primary } \\
\text { EGFR } \\
\text { mutation }\end{array}$} & \multirow[t]{2}{*}{ site } & \multirow[t]{2}{*}{ TKI } & \multicolumn{2}{|c|}{ Primary mutation } & \multicolumn{2}{|c|}{ T790M mutation } & \multicolumn{3}{|c|}{ MET } \\
\hline & & & & Tumor & Plasma & Tumor & Plasma & Tumor & FISH & Plasma \\
\hline 1 & $\begin{array}{c}\text { S752-I759 } \\
\text { del }\end{array}$ & PE & $\mathrm{E}$ & $\mathrm{NE}$ & NE & $\mathrm{p}$ & $\mathrm{p}$ & $\mathrm{n}$ & $\mathrm{n}$ & $\mathrm{n}$ \\
\hline 2 & $\begin{array}{c}\text { E746-A750 } \\
\text { del }\end{array}$ & PE & G & $\mathrm{p}$ & $\mathrm{p}$ & $\mathrm{p}$ & $\mathrm{p}$ & $\mathrm{n}$ & $\mathrm{n}$ & $\mathrm{n}$ \\
\hline 3 & $\begin{array}{c}\text { E746-A750 } \\
\text { del }\end{array}$ & Lung & G & $\mathrm{n}$ & $\mathrm{n}$ & $\mathrm{n}$ & $\mathrm{n}$ & $\mathrm{n}$ & $\mathrm{n}$ & $\mathrm{n}$ \\
\hline 4 & L858R & Lung & G & $\mathrm{p}$ & $\mathrm{n}$ & $\mathrm{n}$ & $\mathrm{n}$ & $\mathrm{p}$ & $\mathrm{n}$ & $\mathrm{n}$ \\
\hline 5 & $\begin{array}{c}\text { E746-A750 } \\
\text { del }\end{array}$ & Lung & G & $\mathrm{p}$ & $\mathrm{p}$ & $\mathrm{p}$ & $\mathrm{p}$ & $\mathrm{n}$ & $\mathrm{n}$ & $\mathrm{n}$ \\
\hline 6 & L858R & $\mathrm{PE}$ & G & $\mathrm{n}$ & $\mathrm{n}$ & $\mathrm{n}$ & $\mathrm{p}$ & $\mathrm{n}$ & $\mathrm{n}$ & $\mathrm{n}$ \\
\hline 7 & L858R & $\mathrm{PE}$ & G & $\mathrm{p}$ & $\mathrm{p}$ & $\mathrm{n}$ & $\mathrm{n}$ & $\mathrm{n}$ & $\mathrm{n}$ & $\mathrm{n}$ \\
\hline 8 & L858R & PCE & G & $\mathrm{p}$ & $\mathrm{n}$ & $\mathrm{p}$ & $\mathrm{p}$ & $\mathrm{n}$ & $\mathrm{n}$ & $\mathrm{n}$ \\
\hline 9 & L858R & $\mathrm{LN}$ & G & $\mathrm{p}$ & $\mathrm{p}$ & $\mathrm{n}$ & $\mathrm{n}$ & $\mathrm{p}$ & $\mathrm{p}$ & $\mathrm{n}$ \\
\hline 10 & L858R & Lung & G & $\mathrm{p}$ & $\mathrm{p}$ & $\mathrm{p}$ & $\mathrm{n}$ & $\mathrm{n}$ & $\mathrm{n}$ & $\mathrm{n}$ \\
\hline 11 & L858R & Lung & $\mathrm{G}$ & $\mathrm{p}$ & $\mathrm{p}$ & $\mathrm{p}$ & $\mathrm{p}$ & $\mathrm{n}$ & $\mathrm{n}$ & $\mathrm{n}$ \\
\hline 12 & L858R & $\mathrm{PE}$ & $\bar{G}$ & $\mathrm{p}$ & $\mathrm{p}$ & $p$ & $\mathrm{p}$ & $\mathrm{n}$ & $\mathrm{n}$ & $\mathrm{n}$ \\
\hline 13 & L858R & $\mathrm{PE}$ & G & $\mathrm{p}$ & $\mathrm{n}$ & $\mathrm{p}$ & $\mathrm{n}$ & $\mathrm{n}$ & $\mathrm{n}$ & $\mathrm{n}$ \\
\hline 14 & $\begin{array}{c}\text { E746-A750 } \\
\text { del }\end{array}$ & Lung & G & $\mathrm{p}$ & $\mathrm{n}$ & $\mathrm{n}$ & $\mathrm{n}$ & $\mathrm{n}$ & $\mathrm{n}$ & $\mathrm{n}$ \\
\hline 15 & L858R & $\mathrm{LN}$ & $\mathrm{G}$ & $\mathrm{p}$ & $\mathrm{n}$ & $\mathrm{n}$ & $\mathrm{n}$ & $\mathrm{n}$ & $\mathrm{n}$ & $\mathrm{n}$ \\
\hline 16 & $\begin{array}{c}\text { E746-A750 } \\
\text { del }\end{array}$ & Lung & G & $\mathrm{p}$ & $\mathrm{p}$ & $\mathrm{p}$ & $\mathrm{p}$ & $\mathrm{p}$ & $\mathrm{n}$ & $\mathrm{n}$ \\
\hline 17 & $\begin{array}{c}\text { E746-A750 } \\
\text { del }\end{array}$ & PE & G & $\mathrm{p}$ & $\mathrm{p}$ & $\mathrm{p}$ & $\mathrm{p}$ & $\mathrm{n}$ & $\mathrm{n}$ & $\mathrm{n}$ \\
\hline 18 & $\begin{array}{c}\text { E746-A750 } \\
\text { del }\end{array}$ & PE & G & $\mathrm{p}$ & $\mathrm{p}$ & $\mathrm{p}$ & $\mathrm{p}$ & $\mathrm{n}$ & $\mathrm{n}$ & $\mathrm{n}$ \\
\hline
\end{tabular}

Abbreviations: EGFR, epidermal growth factor receptor; site, re-biopsy site; TKI, tyrosine kinase inhibitor; FISH, fluorescence in situ hybridization; PE, pleural effusion; PCE, pericardial effusion; LN, lymph node; E, erlotinib; $\mathrm{G}$, gefitinib; NE, not evaluated; $\mathrm{p}$, positive; $\mathrm{n}$, negative.

PCR analysis for T790M may be a promising approach for EGFR mutant NSCLC that has relapsed after EGFR-TKI treatment.

We also analyzed the plasma cfDNA of primary activating EGFR mutation, which had been detected previously in tumors before EGFR-TKI treatment, in matched samples obtained after acquisition of resistance to EGFR-TKI. Our results revealed that primary activating $E G F R$ mutation in plasma had a sensitivity of $66.7 \%$, which was relatively low in comparison to those in previous studies that had examined EGFR mutations in pre-treatment plasma [24], and those for the T790M mutation in the present study. One possible explanation for these discrepancies may be tumor mutational heterogeneity. Several previous studies of NSCLC have demonstrated a discrepancy of EGFR mutation status between the primary tumor and the corresponding metastatic lesions [33-35], and it has been suggested that the EGFR mutation status in the latter may be more associated with favorable efficacy of EGFR-TKI treatment than that in the former [35]. 


\section{Table 3: Concordance of primary EGFR mutation and T790M mutation between tumor samples and plasma samples}

\section{Tumor}

\begin{tabular}{|c|c|c|c|c|c|c|}
\hline & Primary mutation & Positive & Negative & Sensitivity & Specificity & Concordance \\
\hline \multirow[t]{4}{*}{ Plasma } & Positive & 10 & 0 & $66.7 \%$ & $100 \%$ & $70.6 \%$ \\
\hline & Negative & 5 & 2 & & & \\
\hline & Total & 15 & 2 & & & \\
\hline & T790M mutation & Positive & Negative & Sensitivity & Specificity & Concordance \\
\hline \multirow[t]{3}{*}{ Plasma } & Positive & 9 & 1 & $81.8 \%$ & $85.7 \%$ & $83.3 \%$ \\
\hline & Negative & 2 & 6 & & & \\
\hline & Total & 11 & 7 & & & \\
\hline
\end{tabular}

One patient who had a minor mutation involving S752-I759 deletion in exon 19 was not evaluated for primary EGFR mutation.

Discordance of EGFR mutation status has also been reported even among different parts of a primary lung tumor in any given individual [36, 37]. Additionally, Graziano P et al. have reported the co-presence of lesions positive for T790M mutation with lesions that are negative in the same patients with EGFR-mutant NSCLC after development of resistance to EGFR-TKIs [38]. Although T790M mutation was previously thought to be acquired secondarily upon exposure to EGFR-TKI, recent studies have shown that subclones harboring T790M pre-exist in NSCLC patients even before EGFR-TKI treatment $[39,40]$. It has been hypothesized that EGFR-TKI treatment may cause selection of cells harboring T790M mutation, even though they may represent only a small subclone of cancer cells upon initiation of treatment, consequently leading to EGFR-TKI resistance as a result of selective increase of such T790M clones [40]. T790M mutations exists as dominant clones in about $50 \%$ of patients with acquired resistance, and subclonal populations of EGFR mutant tumor cells with or without the T790M mutation can coexist in EGFR mutant NSCLC that has acquired resistance to EGFR-TKIs. A tumor sample obtained using only a single biopsy may not necessarily reflect the dominant properties of the tumor, and the primary activating EGFR mutation appears to represent the non-dominant tumor clone in patients with EGFR-TKI-resistant NSCLC. Indeed, primary activating EGFR mutations in plasma were not detected in third part of cases, even though they were detected in tumor re-biopsy samples. This mutational heterogeneity of tumors might account for the inconsistency between analysis of the primary active mutation and T790M mutation in identical paired samples, suggesting that analysis of blood samples mirrors the dominant properties of the tumor. Our results indicating that plasma samples can be used to detect T790M mutation may provide some patients with an opportunity to receive third-generation EGFR-TKIs.
The MET and HER2 genes have been reported one of the mechanism of acquired resistance to EGFR-TKIs $[9,10]$. Although some studies have investigated HER2 amplification in plasma cfDNA from patients with breast cancer [41-43], no previous study has focused on MET and HER2 in plasma of NSCLC patients. Therefore, in the present study, we attempted to detect MET and HER2 amplifications in both tumor and plasma samples. Our analysis of tumor samples using digital PCR confirmed $M E T$ copy number gain in three patients. However, FISH analysis demonstrated only one patient with MET amplification, and none of the patients had a gain in $M E T$ copy number on the basis of plasma samples. Both MET gene copy number amplification and T790M mutation were detected in case 16. Both genes of these genes are considered to be exclusively involved in the mechanism of resistance to EGFR-TKIs, and these results suggest intratumonal heterogeneity such as the co-presence of clones with MET copy number gain and T790M mutation. The discrepancy between MET copy number gain and T790M mutation in the same case was considered attributable to differences in the detection sensitivity of the assays. Whereas T790M mutation is defined on the basis of detection of positivity for the mutant allele, MET copy number gain is defined by the degree of copy number gain relative to the reference gene. Therefore, admixing of normal cells would influence the detection of MET copy number gain, unlike detection of T790M mutation. Although our results did not allow us to conclude whether digital PCR is helpful for detection of MET and HER2 amplification in plasma samples, we believe that a further large-scale study might clarify this issue.

In conclusion, we have demonstrated that digital PCR analysis of T790M mutation in plasma samples had high sensitivity and specificity in NSCLC patients with resistance to EGFR-TKIs. Although our study was retrospective in nature and had a relatively small sample 
size, our results suggest that digital PCR to detect T790M mutation in plasma samples could be an alternative and non-invasive method for patients with EGFR-positive NSCLC resistance to first- or second-generation EGFRTKIs, especially patients from whom tumor lesions can be collected safely. In the future, plasma cfDNA may become a standard detection modality for analysis of EGFR mutations including T790M mutation.

\section{MATERIALS AND METHODS}

\section{Patients}

We retrospectively screened 152 consecutive EGFR mutation-positive NSCLC patients who had received EGFR-TKI treatment at Kurume University Hospital between 2007 and 2014. Among these patients, both tumor specimens and blood samples were obtained from 18 with appropriate tumor DNA after acquisition of resistance to EGFR-TKI treatment.

The present study was conducted in accordance with the provisions of the Declaration of Helsinki, and was approved by the Institutional Review Board of Kurume University Hospital.

\section{Sample collection and processing}

We used formalin-fixed, paraffin-embedded sections or fresh frozen samples of tumors after acquisition of resistance to treatment with EGFR-TKIs. For plasma samples, 7 to $10 \mathrm{~mL}$ of peripheral blood was collected in heparin-coated tubes from patients after they had acquired resistance to EGFR-TKI treatment. Plasma was removed by centrifugation at $1000 \mathrm{rpm}$ for $15 \mathrm{~min}$ within two hours of collection and stored at $-80^{\circ} \mathrm{C}$ until DNA extraction. Plasma DNA was purified using a QIAamp Circulating Nucleic Acid Kit (Qiagen, Valencia, CA) in accordance with the manufacturer's instructions. The extracted DNA was stored at $4^{\circ} \mathrm{C}$ until analysis.

\section{Digital PCR analysis}

Mutant allele frequency was measured using the QX100 Droplet Digital PCR System in accordance with the manufacturer's instructions (Bio-Rad, Hercules, CA). The primers and probes for detecting EGFR E746-A750 deletion, L858R, and T790M were purchased from Bio-Rad. The PCR reaction was performed using the following cycling conditions: $95^{\circ} \mathrm{C}$ for $10 \mathrm{~min}$, 40 cycles of $94^{\circ} \mathrm{C}$ for $30 \mathrm{~s}$ and $55^{\circ} \mathrm{C}$ for $60 \mathrm{~s}$, followed by enzyme deactivation at $98^{\circ} \mathrm{C}$ for $10 \mathrm{~min}$. For MET copy number assay, the primer sequences were: MET forward, 5'-TTAGTTCGCTACGATGCAAGAG-3; MET reverse, 5'-GGCTTACACTTCGGGCACT-3'; MET probe, 5'-/56FAM/CACACTCCT/ZEN/CATTTGGATAGGCTTG/3IB $\kappa \mathrm{FQ} /-3^{\prime}$; RPP30 forward, 5'-GATTTGGACCTGCGAG CG-3'; RPP30 reverse, 5'-GCGGCTGTCTCCACAA
GT-3'; RPP30 probe, 5'-/5HEX/CTGACCTGAAGGCT $\mathrm{CT} / 3 \mathrm{IABkFQ} / \mathrm{3}^{\prime}$. The $\mathrm{PCR}$ reaction was performed using the following cycling conditions: $95^{\circ} \mathrm{C}$ for $10 \mathrm{~min}$, 40 cycles of $94^{\circ} \mathrm{C}$ for $30 \mathrm{~s}$ and $60^{\circ} \mathrm{C}$ for $90 \mathrm{~s}$, followed by enzyme deactivation at $98^{\circ} \mathrm{C}$ for $10 \mathrm{~min}$. For HER 2 copy number assay, the primer sequences were: HER2 forward, 5'-ACAACCAAGTGAGGCAGGTC-3'; HER2 reverse, 5'-GTATTGTTCAGCGGGTCTCC-3'; HER2 probe, 5'-/56-FAM/AGGCACCC A/ZEN/GCTCTTTGAGGA CAAC/3IABkFQ/-3'; EFTUD2 forward, 5'-GGTCTTGCC AGACACCAAAG-3'; EFTUD2 reverse, 5'-TGAGAGGA CACACGCAAAAC-3'; EFTUD2 probe, 5'- /5HEX/TC CAGGTAG/ZEN/GACATCCTTTGGCTTT/3IABkFQ/-3' [30]. The PCR reaction was performed using the following cycling conditions: $95^{\circ} \mathrm{C}$ for $10 \mathrm{~min}, 40$ cycles of $94^{\circ} \mathrm{C}$ for $30 \mathrm{~s}$ and $58^{\circ} \mathrm{C}$ for $90 \mathrm{~s}$, followed by enzyme deactivation at $98^{\circ} \mathrm{C}$ for $10 \mathrm{~min}$. After thermal cycling, the plates were transferred to a Droplet reader. The digital PCR data were analyzed using the QuantaSoft analytical software package (Bio-Rad). We have used control plasmids encoding wildtype EGFR, E746-A750 deletion, L858R, and a T790M mutant as a control. The assay has been validated to detect mutant variants at a level of $0.032 \%$.

The cutoff values for DNA derived from the FFPE specimens were determined using data for mutationnegative FFPE samples. The average and standard deviation (SD) for EGFR E746-A750 deletion, L858R, and T790M mutant copy number in 21 FFPE samples were calculated. The average copy number for negative samples plus 3SD was used as the cut-off value for each mutation site; the higher value of either, the average plus $3 \mathrm{SD}$ or three copies was used as the cut-off value. The cutoff values were set at 6.0 copies for EGFR E746-A750, 4.0 copies for EGFR L858R, and 22.0 copies for EGFR T790M. The cut-off values for DNA derived from plasma or frozen samples were determined using data for 10 normal DNA samples. The cut-off values were set at 3.0 copies for EGFR E746-A750, L858R, and T790M. MET and HER2 gene copy numbers were normalized against RPP30 and EFTUD2, respectively. Normal genomic DNA (Promega, Madison, WI) was used as the normal control (two copies). The cut-off values were set at 5.0 copies for MET and HER2 copy number gain.

\section{Fluorescence in situ hybridization for MET}

Fluorescence in situ hybridization (FISH) was performed to determine the MET copy number in FFPE tumor specimens using a c-Met/CEN7p Dual Color FISH Probe (GSP Laboratory, Kawasaki, Japan), where CEN7p is the centromeric region of chromosome $7 \mathrm{p}$. After screening of all sections, images of tumor cells were captured and recorded, and the signals for at least 50 random nuclei were counted for an area in which individual cells were recognized in each of at least 10 representative images. Nuclei with a disrupted boundary were excluded from the analysis. Gene 
amplification was strictly defined on the basis of a mean MET/CEN7p copy number ratio of $>2.2$, as described previously [44].

\section{Analysis for sensitivity and specificity}

Sensitivity was defined as the probability of detecting plasma positive positivity findings in plasma among patients with for whom the presence of the mutation had been confirmed in tumor samples, and whereas specificity was defined as the probability to of detecting plasma negative negativity in plasma among patients without who did not harbor the mutation in tumor samples.

\section{ACKNOWLEDGMENTS}

We thank Ms. Chie Ohki (Kurume University, Fukuoka, Japan) for her technical assistance.

\section{CONFLICTS OF INTEREST}

The authors have no conflicts of interest to declare.

\section{FUNDING}

This work was supported by funding for Applied Research for Innovative Treatment of Cancer (Subject No.14525177 to K.N.) from the Ministry of Health, Labour and Welfare of Japan.

\section{REFERENCES}

1. Siegel R, Naishadham D, Jemal A. Cancer statics. CA Cancer J Clin. 2012; 62:10-29.

2. Mok TS, Wu YL, Thongprasert S, Yang CH, Chu DT, Saijo N, Sunpaweravong P, Han B, Margono B, Ichinose Y, Nishiwaki Y, Ohe Y, Yang JJ, et al. Gefitinib or carboplatin-paclitaxel in pulmonary adenocarcinoma. N Engl J Med. 2009; 361:947-957.

3. Maemondo M, Inoue A, Kobayashi K, Sugawara S, Oizumi S, Isobe H, Gemma A, Harada M, Yoshizawa H, Kinoshita I, Fujita Y, Okinaga S, Hirano H, et al. Gefitinib or chemotherapy for non-small-cell lung cancer with mutated EGFR. N Engl J Med. 2010; 362:2380-2388.

4. Mitsudomi T, Morita S, Yatabe Y, Negoro S, Okamoto I, Tsurutani J, Seto T, Satouchi M, Tada H, Hirashima T, Asami K, Katakami N, Takada M, et al. Gefitinib versus cisplatin plus docetaxel in patients with non-small-cell lung cancer harboring mutations of the epidermal growth factor receptor (WJTOG3405): an open label, randomized phase 3 trial. Lancet Oncol. 2010; 11:121-128.

5. Zhou C, Wu YL, Chen G, Feng J, Liu XQ, Wang C, Zhang S, Wang J, Zhou S, Ren S, Lu S, Zhang L, Hu C, et al. Erlotinib versus chemotherapy as first-line treatment for patients with advanced EGFR mutation-positive non-small-cell lung cancer (OPTIMAL, CTONG-0802): a multicenter, openlabel, randomized, phase 3 study. Lancet Oncol. 2011; 12:735-742.

6. Rosell R, Carcereny E, Gervais R, Vergnenegre A, Massuti B, Felip E, Palmero R, Garcia-Gomez R, Pallares C, Sanchez JM, Porta R, Cobo M, Garrido P, et al. Erlotinib versus chemotherapy as first-line treatment for patients with advanced EGFR mutation-positive non-smallcell lung cancer (EURTAC): a multicenter, open-label, randomized, phase 3 trial. Lancet Oncol. 2012; 13:239-246.

7. Sequist LV, Yang JC, Yamamoto N, O’Byrne K, Hirsh V, Mok T, Geater SL, Orlov S, Tsai CM, Boyer M, Su WC, Bennouna J, Kato T, et al. Phase III study of afatinib or cisplatin plus pemetrexed in patients with metastatic lung adenocarcinoma with EGFR mutations. J Clin Oncol. 2013; 31:3327-3334.

8. Sequist LV, Waltman BA, Dias-Santagata D, Digumarthy S, Turke AB, Fidias P, Bergethon K, Shaw AT, Gettinger S, Cosper AK, Akhavanfard S, Heist RS, Temel J, et al. Genotypic and histological evolution of lung cancers acquiring resistance to EGFR inhibitors. Sci Transl Med. 2011; 3:75ra26.

9. Engelman JA, Zejnuliahu K, Mitsudomi T, Song Y, Hyland C, Park JO, Lindeman N, Gale CM, Zhao X, Christensen J, Kosaka T, Holmes AJ, Rogers AM, et al. MET amplification leads to gefitinib resistance in lung cancer by activating ERBB3 signaling. Science. 2007; 316:1039-1043.

10. Takezawa K, Parazzoli V, Arcila ME, Nebhan CA, Song X, de Stanchina E, Ohashi K, Janjigian YY, Spitzler PJ, Melnick MA, Riely GJ, Kris MG, Miller VA, et al. HER2 amplification: a potential mechanism of acquired resistance to EGFR inhibition in EGFR-mutant lung cancers that lack the second-site EGFR T790M mutation. Cancer Discov. 2012; 2:922-933.

11. Cross DA, Ashton SE, Ghiorghiu S, Eberlein C, Nebhan CA, Spitzler PJ, Orme JP, Finlay MR, Ward RA, Mellor MJ, Hughes G, Rahi A, Jacobs VN, et al. AZD9291, an irreversible EGFR, TKI, overcomes T790M-mediated resistance to EGFR inhibitors in lung cancer. Cancer Discov. 2014; 4:1046-1061.

12. Steuer CE, Khuri FR, Ramalingam SS. The next generation of epidermal growth factor receptor tyrosine kinase inhibitors in the treatment of lung cancer. Cancer. 2015; 121:E1-6.

13. Janjigian YY, Smit EF, Groen HJ, Horn L, Gettinger S, Camidge DR, Riely GJ, Wang B, Fu Y, Chand VK, Miller VA, Pao W. Dual inhibition of EGFR with afatinib and cetuximab in kinase inhibitor-resistant EGFR-mutant lung cancer with and without T790M mutations. Cancer Discov. 2014; 4:1036-1045.

14. Sequist LV, Pawel JV, Garmey EG, Akerley WL, Brugger W, Ferrari D, Chen Y, Costa DB, Gerber DE, 
Orlov S, Ramlau R, Arthur S, Gorbachevsky I, et al. Randomized phase II study of erlotinib plus tivantinib versus erlotinib plus placebo in previously treated nonsmall-cell lung cancer. J Clin Oncol. 2011; 29:3307-3315.

15. Sozzi G, Conte D, Leon M, Ciricione R, Roz L, Ratcliffe C, Roz E, Cirenei N, Bellomi M, Pelosi G, Pierotti MA, Pastorino U. Quantification of free circulating DNA as a diagnostic marker in lung cancer. J Clin Oncol. 2003; 21:3902-3908.

16. Kimura H, Suminoe M, Kasahara K, Sone T, Araya T, Tamori S, Koizumi F, Nishio K, Miyamoto K, Fujimura M, Nakao S. Evaluation of epidermal growth factor receptor mutation status in serum DNA as a predictor of response to gefitinib (IRESSA). Br J Cancer. 2007; 97:778-784.

17. Goto K, Ichinose Y, Ohe Y, Yamamoto N, Negoro S, Nishio K, Itoh Y, Jiang H, Duffield E, McCormack R, Saijo N, Mok T, Fukuoka M. Epidermal growth factor receptor mutation status in circulating free DNA in serum: from IPASS, a phase III study of gefitinib or carboplatin/ paclitaxel in non-small cell lung cancer. J Thorac Oncol. 2012; 7:115-121.

18. Kimura H, Kasahara K, Kawaishi M, Kunitoh H, Tamura T, Holloway B, Nishio K. Detection of epidermal growth factor receptor mutations in serum as a predictor of the response to gefitinib in patients with non-small-cell lung cancer. Clin Cancer Res. 2006; 12:3915-3921.

19. Kuang Y, Rogers A, Yeap BY, Wang L, Makrigiorgos M, Vetrand K, Thiede S, Distel RJ, Jänne PA. Noninvasive detection of EGFR T790M in gefitinib or erlotinib resistant non-small cell lung cancer. Clin Cancer Res. 2009; 15:2630-2636.

20. Bai H, Mao L, Wang HS, Zhao J, Yang L, An TT, Wang X, Duan CJ, Wu NM, Guo ZQ, Liu YX, Liu HN, Wang YY, Wang J. Epidermal growth factor receptor mutations in plasma DNA samples predict tumor response in Chinese patients with stages IIIB to IV non-small-cell lung cancer. J Clin Oncol. 2009; 27:2653-2659.

21. Brevet M, Johnson ML, Azzoli CG, Ladanyi M. Detection of EGFR mutations in plasma DNA from lung cancer patients by mass spectrometry genotyping is predictive of tumor EGFR status and response to EGFR inhibitor. Lung Cancer. 2011; 73:96-102.

22. Jiang B, Liu F, Yang L, Zhang W, Yuan H, Wang J, Huang G. Serum detection of epidermal growth factor receptor gene mutations using mutant-enriched sequencing in Chinese patients with advanced non-small cell lung cancer. J Int Med Res. 2011; 39:1392-1401.

23. Kim ST, Jung HY, Sung JS, Jo UH, Tanaka T, Hagiwara K, Park KH, Shin SW, Kim JS, Kim YH. Can serum be used for analyzing the EGFR mutation status in patients with advanced nonsmall cell lung cancer? Am J Clin Oncol. 2013; 36:57-63.

24. Yung TK, Chan KC, Mok TS, Tong J, To KF, Lo YM. Single-molecule detection of epidermal growth factor receptor mutations in plasma by microfluidics digital PCR in non-small cell lung cancer patients. Clin Cancer Res. 2009; 15:2076-2084.

25. Baker M. Digital PCR hits its stride. Nature Methods. 2012; 9:541-544.

26. Wang Z, Chen R, Wang S, Zhong J, Wu M, Zhao J, Duan J, Zhuo M, An T, Wang Y, Bai H, Wang J. Quantification and dynamic monitoring of EGFR T790M in plasma cell-free DNA by digital PCR for prognosis of EGFR-TKI treatment in advanced NSCLC. PLoS One. 2014; 9:e110780.

27. Goto K, Ichinose Y, Ohe Y, Yamamoto N, Negoro S, Nishio K, Itoh Y, Jiang H, Duffield E, McCormack R, Saijo N, Mok T, Fukuoka M. Epidermal growth factor receptor mutation status in circulating free DNA in serum: from IPASS, a phase III study of gefitinib or carboplatin/ paclitaxel in non-small cell lung cancer. J Thorac Oncol. 2012; 7:115-121.

28. Kuang Y, Rogers A, Yeap BY, Wang L, Makrigiorgos M, Vetrand K, Thiede S, Distel RJ, Jänne PA. Noninvasive detection of EGFR T790M in gefitinib or erlotinib resistant non-small cell lung cancer. Clin Cancer Res. 2009; 15:2630-2636.

29. Sakai K, Horiike A, Irwin DL, Kudo K, Fujita Y, Tanimoto A, Sakatani T, Saito R, Kaburaki K, Yanagitani N, Ohyanagi F, Nishio M, Nishio K. Detection of epidermal growth factor receptor T790M mutation in plasma DNA from patients refractory to epidermal growth factor receptor tyrosine kinase inhibitor. Cancer Sci. 2013; 104:1198-1204.

30. Oxnard GR, Pawelets CP, Kuang Y, Mach SL, O'Connell A, Messineo MM, Luke JJ, Butaney M, Kirschmeier P, Jackman DM, Jänne PA. Noninvasive detection of response and resistance in EGFR-mutant lung cancer using quantitative next-generation genotyping of cell-free plasma DNA. Clin Cancer Res. 2014; 20:1698-1705.

31. Sorensen BS, Wu L, Wei W, Tsai J, Weber B, Nexo E, Meldgaard P. Monitoring of epidermal growth factor receptor tyrosine kinase inhibitor-sensitizing and resistance mutations in the plasma DNA of patients with advanced non-small cell lung cancer during treatment with erlotinib. Cancer. 2014; 120:3896-3901.

32. Jänne PA, Yang JC, Kim DW, Planchard D, Ohe Y, Ramalingam SS, Ahn MJ, Kim SW, Su WC, Horn L, Haggstrom D, Felip E, Kim JH, et al. AZD9291 in EGFR inhibitor-resistant non-small-cell lung cancer. N Engl J Med. 2015; 372:1689-1699.

33. Park S, Holmes-Tisch AJ, Cho EY, Shim YM, Kim J, Kim HS, Lee J, Park YH, Ahn JS, Park K, Jänne PA, Ahn MJ. Discordance of molecular biomarkers associated with epidermal growth factor receptor pathway between primary tumors and lymph node metastasis in non-small cell lung cancer. J Thorac Oncol. 2009; 4:809-815.

34. Schmid K, Oehl N, Wrba F, Pirker R, Pirker C, Filipits M. EGFR/KRAS/BRAF mutations in primary lung 
adenocarcinomas and corresponding locoregional lymph node metastases. Clin Cancer Res. 2009; 15:4554-4560.

35. Shimizu K, Yukawa T, Hirami Y, Okita R, Saisho S, Maeda A, Yasuda K, Nakata M. Heterogeneity of the EGFR mutation status between the primary tumor and metastatic lymph node and the sensitivity to EGFR tyrosine kinase inhibitor in non-small cell lung cancer. Target Oncol. 2013; 8:237-42.

36. Taniguchi K, Okami J, Kodama K, Higashiyama M, Kato K. Intratumor heterogeneity of epidermal growth factor receptor mutations in lung cancer and its correlation to the response to gefitinib. Cancer Sci. 2008; 99:929-935.

37. Sakurada A, Lara-Guerra H, Liu N, Shepherd FA, Tsao MS. Tissue heterogeneity of EGFR mutation in lung adenocarcinoma. J Thorac Oncol. 2008; 3:527-529.

38. Graziano P, de Marinis F, Gori B, Gasbarra R, Migliorino R, De Santis S, Pelosi G, Leone A. EGFR-Driven Behavior and Intrapatient T790M Mutation Heterogeneity of NonSmall-Cell Carcinoma With Squamous Histology. J Clin Oncol. 2014; Apr 21. [Epub ahead of print].

39. Su KY, Chen HY, Li KC, Kuo ML, Yang JC, Chan WK, Ho BC, Chang GC, Shih JY, Yu SL, Yang PC. Pretreatment epidermal growth factor receptor (EGFR) T790M mutation predicts shorter EGFR tyrosine kinase inhibitor response duration in patients with non-small-cell lung cancer. J Clin Oncol. 2012; 30:433-440.

40. Inukai M, Toyooka S, Ito S, Asano H, Ichihara S, Soh J, Suehisa H, Ouchida M, Aoe K, Aoe M, Kiura K, Shimizu N,
Date H. Presence of epidermal growth factor receptor gene T790M mutation as a minor clone in non-small cell lung cancer. Cancer Res. 2006; 66:7854-7858.

41. Gevensleben H, Garcia-Murillas I, Graeser MK, Schiavon G, Osin P, Parton M, Smith IE, Ashworth A, Turner NC. Noninvasive detection of HER2 amplification with plasma DNA digital PCR. Clin Cancer Res. 2013; 19:3276-84.

42. Rothe F, Leas JF, Lambrechts D, Smeets D, Vincent D, Maetens M, Fumagalli D, Michiels S, Drisis S, Moerman C, Detiffe JP, Larsimont D, Awada A, et al. Plasma circulating tumor DNA as an alternative to metastatic biopsies for mutational analysis in breast cancer. Ann Oncol. 2014; 25:1959-1965.

43. Page K, Hava N, Ward B, Brown J, Guttery DS, Ruangpratheep C, Blighe K, Sharma A, Walker RA, Coombes RC, Shaw JA. Detection of HER2 amplification in circulating free DNA in patients with breast cancer. Br J Cancer. 2011; 104:1342-1348.

44. Wolff AC, Hammond ME, Hicks DG, Dowsett M, McShane LM, Allison KH, Allred DC, Bartlett JM, Bilous M, Fitzgibbons P, Hanna W, Jenkins RB, Mangu PB, et al. Recommendations for human epidermal growth factor receptor 2 testing in breast cancer: American Society of Clinical Oncology/College of American Pathologists clinical practice guideline update. J Clin Oncol. 2013; 31:3997-4013. 